Supplemental Information for

\title{
Relationships Between the Physicochemical Properties of Dissolved Organic Matter and its Reaction with Sodium Borohydride
}

\author{
Hang Li and Garrett McKay* \\ Zachry Department of Civil \& Environmental Engineering, Texas A\&M University, College \\ Station, TX 77845
}

*Corresponding author: Garrett McKay, gmckay@tamu.edu

Number of pages: 16

Number of text sections: 2

Number of tables: 5

Number of figures: 14

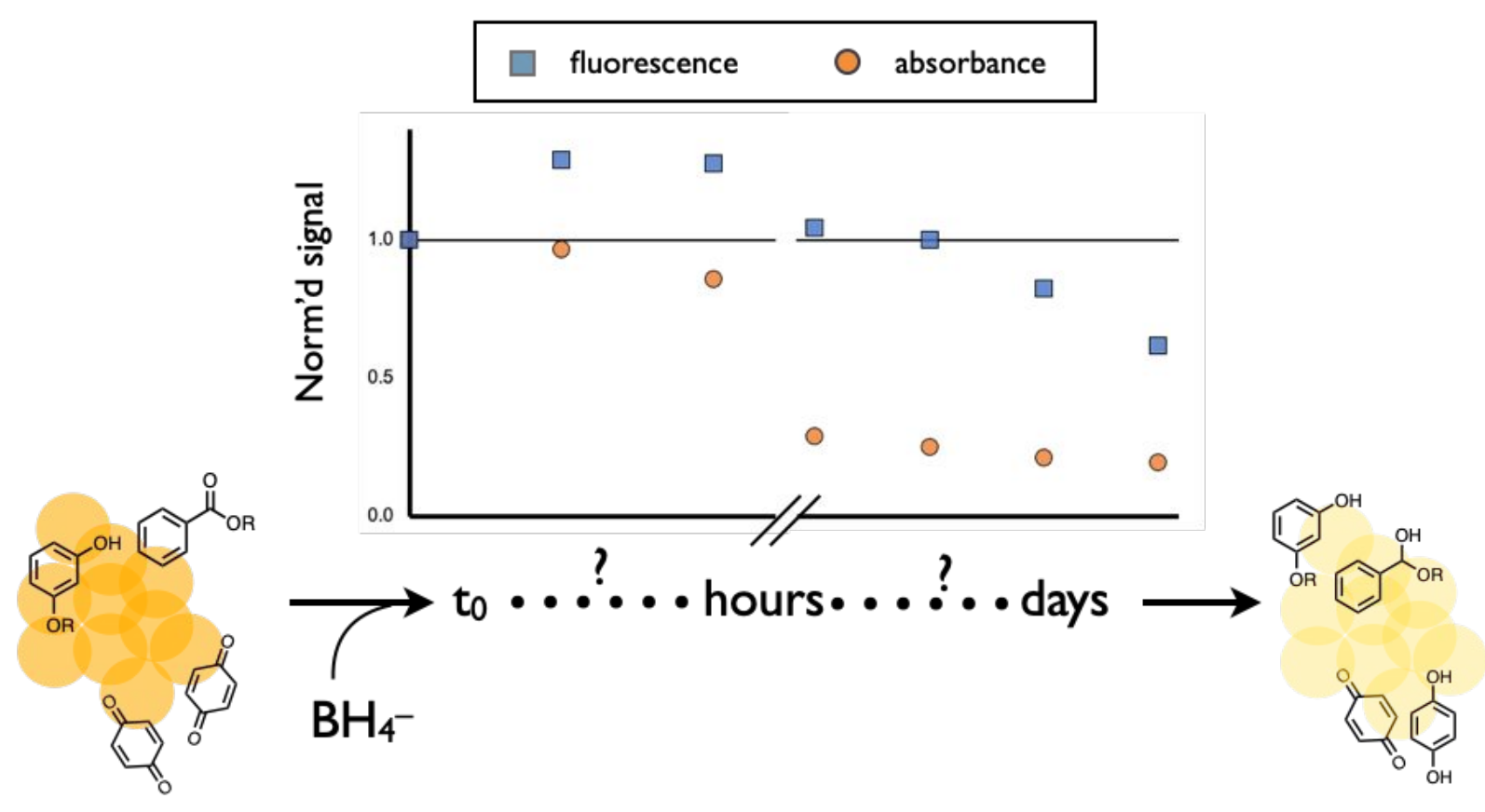




\section{$\underline{\text { Supplementary Text }}$}

Text S1. Materials and Methods.

Chemicals and DOM solutions. A list of chemicals used and their sources is provided in SI Table $\mathrm{S}$ 1. DOM isolates were obtained from the International Humic Substances Society (IHSS, Table S2) and included Pony Lake fulvic acid (PLFA), Suwannee River fulvic acid (SRFA), Suwannee River humic acid (SRHA), Mississippi River natural organic matter (MRNOM), Elliot Soil humic acid (ESHA), Pahokee Peat humic acid (PPHA), and Pahokee Peat fulvic acid (PPFA). Lab grade water was obtained from a Barnstead Nanopure Purification System (Thermo Scientific) that registered an $18.2 \mathrm{M} \Omega-\mathrm{cm}$ resisitivity.

DOM solutions were prepared by dissolving solid isolate in lab grade water at a concentration of $\sim 100 \mathrm{mg} / \mathrm{L}$. Samples were adjusted to $\mathrm{pH} 7.0 \pm 0.1$ with small additions $0.2 \mathrm{M} \mathrm{NaOH}$. Working stock solutions (between $\sim 15$ and $40 \mathrm{mg} / \mathrm{L}$ ) were prepared from this $100 \mathrm{mg} / \mathrm{L}$ stock by diluting to a pre-determined concentration, re-adjusting the $\mathrm{pH}$ to $7.0 \pm 0.1$, and filtering through prewashed $0.45 \mu \mathrm{m}$ syringe filters (polyether sulfone). All DOM stock solutions were kept at $4{ }^{\circ} \mathrm{C}$ prior to use.

Analytical measurements. $\mathrm{pH}$ measurements were made with a Thermo Scientific Orion Veristar $\mathrm{pH}$ meter and a combination $\mathrm{pH}$ electrode or microelectrode following a three-point calibration (4, 7, and 10).

Optical measurements were performed using an Aqualog spectrofluorometer (Horiba Scientific). Daily quality control procedures included verifying the excitation maximum of the Xearc lamp (467 nm) and position of the Raman water peak emission maximum at $350 \mathrm{~nm}$ excitation (397 $\pm 1 \mathrm{~nm})$. All DOM scans utilized a medium gain setting, $2.33 \mathrm{~nm}$ emission bin, and excitation from 800 to $240 \mathrm{~nm}$ in $5 \mathrm{~nm}$ increments. The excitation and emission bandpass in the Aqualog is fixed at $5 \mathrm{~nm}$. Data correction including blank subtraction, Rayleigh masking, inner filter corrections, and Raman normalization were performed in MATLAB (R2020a). Scans for Raman normalization were collected at $350 \mathrm{~nm}$ excitation using the same gain and emission bin settings as for DOM, but with a $10 \mathrm{~s}$ integration time. Raman areas were normalized to the actual integration time used for DOM samples (either 0.2 or $0.5 \mathrm{~s}$ ) prior to normalizing DOM fluorescence to Raman area. DOM concentrations were chosen to maximize fluorescence signal while maintaining a low enough optical density to allow for successful application of inner filter corrections. ${ }^{1}$

Size exclusion chromatography (SEC) was performed to determine the size distribution of DOM. Briefly, an Agilent 1100 high-pressure liquid chromatograph equipped with a protein-pak column (Waters) and UV detector (monitored at $254 \mathrm{~nm}$ ) was used. The mobile phase (10 mM phosphate buffer solution ( $\mathrm{pH}$ 6.8) and $0.5 \mathrm{M}$ sodium sulfate) was pumped at a flow rate of 0.7 $\mathrm{mL} / \mathrm{min}$. Sample conductivity was matched to the eluent prior to sample injection. Retention time was calibrated to molecular weight using poly(styrene) sulfonate sodium standards between 210 and $17,000 \mathrm{Da}$ from PolySciences. Number-average $\left(M_{\mathrm{n}}\right)$ and weight-average $\left(M_{\mathrm{w}}\right)$ were calculated as described previously. ${ }^{2}$ 
Text S2. Comparison of characterization data amongst humic substance isolates

The below tables compare characterization data between different catalog numbers for a single IHSS sampling location in an effort to justify use of $Q_{\mathrm{pH} 10}$ and EAC values to correlate to measured borohydride reduction. The following symbols are used as a reference: $*=$ lot number in our study; \& = lot number used by Aeschbacher et al. ${ }^{3,4}$ Acidic functional groups are derived from http://humic-substances.org/acidic-functional-groups-of-ihss-samples/. ${ }^{5,6}$

${ }^{13} \mathrm{C}-N M R$ estimates of functional group distribution for aquatic and terrestrial humic acids (SRHA and ESHA).

\begin{tabular}{|l|c|c|c|c|c|c|c|}
\hline & Cat. No. & Carbonyl & Carboxyl & Aromatic & Acetal & Heteroaliphatic & Aliphatic \\
\hline Suwannee River I & $1 \mathrm{~S} 101 \mathrm{H}$ & 8 & 19 & 37 & 9 & 7 & 21 \\
\hline Suwannee River II\& & $2 \mathrm{~S} 101 \mathrm{H}$ & 6 & 15 & 31 & 7 & 13 & 29 \\
\hline Suwannee River III* & $3 \mathrm{~S} 101 \mathrm{H}$ & 3.9 & 12.8 & 35.3 & 8.9 & 13.4 & 23.9 \\
\hline Elliott Soil I\& $^{\text {\& }}$ & $1 \mathrm{~S} 102 \mathrm{H}$ & 6 & 18 & 50 & 4 & 6 & 16 \\
\hline Elliott Soil IV & $4 \mathrm{~S} 102 \mathrm{H}$ & 1 & 11 & 41 & 6 & 14 & 27 \\
\hline Elliott Soil V* & $5 \mathrm{~S} 102 \mathrm{H}$ & 1.0 & 14.8 & 48.3 & 5.1 & 9.6 & 16.2 \\
\hline
\end{tabular}

${ }^{13} \mathrm{C}$-NMR estimates of functional group distribution for aquatic and terrestrial fulvic acids (SRFA and PPFA).

\begin{tabular}{|l|l|c|c|c|c|c|c|}
\hline & Cat. No. & Carbonyl & Carboxyl & Aromatic & Acetal & Heteroaliphatic & Aliphatic \\
\hline Suwannee River I & 1S101F & 7 & 20 & 24 & 5 & 11 & 33 \\
\hline Suwannee River II & 2 S101F\& $^{2}$ & 5 & 17 & 22 & 6 & 16 & 35 \\
\hline Suwannee River III & $3 S_{101 F^{*}}$ & 4.2 & 15.6 & 28.9 & 8.1 & 13.3 & 27.4 \\
\hline Pahokee Peat I & 1 S103F*\& & 7 & 28 & 34 & 3 & 9 & 20 \\
\hline Pahokee Peat II & 2S103F & 3.6 & 18.7 & 39.0 & 6.0 & 10.9 & 18.4 \\
\hline
\end{tabular}




\section{Supplementary Tables}

Table S 1. List of chemicals used in this study.

\begin{tabular}{|l|l|c|}
\hline Chemical & Cas \# & Purity \\
\hline Sodium borohydride & $16940-66-2$ & $>98.0 \%$ \\
\hline Hydrochloric acid $(2.0 \mathrm{~N})$ & $7647-01-0$ & - \\
\hline Sodium hydroxide & $1310-73-2$ & $>95 \%$ \\
\hline
\end{tabular}

Table S 2. DOM isolates, abbreviations, and catalog numbers from the International Humic Substances Society.

\begin{tabular}{|l|c|}
\hline DOM isolate & IHSS Catalog \# \\
\hline Elliot Soil humic acid (ESHA) & $5 \mathrm{~S} 102 \mathrm{H}$ \\
\hline Mississippi River natural organic matter (MRNOM) & $1 \mathrm{R} 110 \mathrm{~N}$ \\
\hline Pahokee Peat fulvic acid (PPFA) & $1 \mathrm{~S} 103 \mathrm{~F}$ \\
\hline Pahokee Peat humic acid (PPHA) & $1 \mathrm{~S} 103 \mathrm{H}$ \\
\hline Pony Lake fulvic acid (PLFA) & $1 \mathrm{R} 109 \mathrm{~F}$ \\
\hline Suwannee River fulvic acid (SRFA) & $3 \mathrm{~S} 101 \mathrm{~F}$ \\
\hline Suwannee River humic acid (SRHA) & $3 \mathrm{~S} 101 \mathrm{H}$ \\
\hline
\end{tabular}

Table S 3. Calculation of total charge density $\left(Q_{\mathrm{pH} 10}, \mathrm{meq} / \mathrm{gHS}\right)$ based on charge densities, average equilibrium constants $(\mathrm{K})$ and empirical parameters (n) from $\mathrm{pH}$ titration data of humic substance isolates. Calculation based on Ritchie and Perdue.

\begin{tabular}{|l|l|l|l|l|l|l|l|l|}
\hline DOM isolate & $\begin{array}{c}\text { IHSS } \\
\text { Catalog } \\
\#\end{array}$ & $Q_{1}$ & $K_{1}$ & $n_{1}$ & $Q_{2}$ & $K_{2}$ & $n_{2}$ & $Q_{\mathrm{pH} 10}$ \\
\hline ESHA & 1S102H & 8.90 & 4.36 & 3.16 & 0.85 & 9.80 & 1.00 & 9.277 \\
\hline LHA & 1S104H & 4.59 & 4.59 & 3.32 & 1.13 & 9.72 & 1.31 & 8.684 \\
\hline MRNOM & 1R110N & 12.51 & 3.47 & 2.69 & 0.91 & 10.00 & 1.00 & 12.918 \\
\hline PLFA & 1R109F & 6.91 & 4.52 & 1.82 & 1.43 & 9.48 & 1.77 & 7.848 \\
\hline PPHA & 1S103H & 9.64 & 4.22 & 3.20 & 0.94 & 9.86 & 1.00 & 10.037 \\
\hline PPFA & 1S101F & 14.22 & 3.99 & 3.33 & 0.76 & 9.57 & 1.00 & 14.555 \\
\hline SRFA & 2S101F & 11.66 & 3.76 & 3.24 & 2.05 & 9.84 & 1.45 & 12.678 \\
\hline SRHA & 2S101H & 9.74 & 4.35 & 3.30 & 4.48 & 10.44 & 1.73 & 11.157 \\
\hline
\end{tabular}


Table S 4. Physicochemical properties of DOM isolates employed in this study

\begin{tabular}{|l|c|c|c|c|c|c|c|}
\hline Sample & $\mathbf{F I}$ & $\begin{array}{c}\mathbf{S}_{\mathbf{3 0 0 - 6 0 0}} \\
\mathbf{( n m}^{-1} \mathbf{)}\end{array}$ & $\begin{array}{c}\text { EAC } \\
(\boldsymbol{\mu m o l ~ e - ~} \\
\text { /gHS) }\end{array}$ & $\begin{array}{c}\mathbf{M n} \\
\mathbf{( D a )}\end{array}$ & $\begin{array}{c}\mathbf{M w} \\
\mathbf{( D a )}\end{array}$ & $\begin{array}{c}\mathbf{M n * Q} \\
\text { (charge/molec) }\end{array}$ & $\begin{array}{c}\mathbf{M} \mathbf{w}^{* \mathbf{Q}} \\
\text { (charge/molec) }\end{array}$ \\
\hline SRFA & 1.29 & 0.0152 & 671 & 1436 & 5278 & 9.5 & 35.0 \\
SRHA & 1.09 & 0.013 & 962 & 2329 & 9159 & 13.7 & 53.8 \\
MRNOM & 1.45 & 0.0161 & 750 & 1611 & 4733 & 10.4 & 30.6 \\
PLFA & 1.58 & 0.0155 & 493 & 909 & 3519 & 3.7 & 14.5 \\
ESHA & 0.65 & 0.0075 & 1962 & 2399 & 16489 & 13.1 & 90.2 \\
PPHA & 0.74 & 0.0098 & 1684 & 2591 & 15359 & 14.7 & 86.9 \\
PPFA & 1.06 & 0.0134 & 992 & 2310 & 6863 & 17.0 & 50.4 \\
LHA & 0.931 & 0.011 & 1711 & 2032 & 13966 & 11.3 & 77.4 \\
\hline
\end{tabular}


Table S 5. Pearson's correlation coefficients for DOM physicochemical properties and optical metrics describing the extent of borohydride reduction. DOM physicochemical properties include fluorescence index (FI), spectral slope (S), electron accepting capacity (EAC), number-average $(\mathrm{Mn})$ and weight-average molecular weight $(\mathrm{Mw})$, and number-average $\left(\mathrm{Q}^{*} \mathrm{Mn}\right)$ and weightaverage $\left(\mathrm{Q}^{*} \mathrm{Mw}\right)$ charge. $\Delta \mathrm{A}_{\text {short }}$ and $\Delta \mathrm{A}_{\text {long }}$ refer to the absorbance difference at $10 \mathrm{~min}$ and $20 \mathrm{hr}$, respectively, $\mathrm{A}_{0}$ refers to the $\mathrm{pH} 10$ unreduced sample.

\begin{tabular}{|c|ccccc|}
\hline \multicolumn{5}{|c|}{ Pearson's correlation coefficients } \\
\hline & \multicolumn{5}{|c|}{$\mathrm{A}_{\text {short }} / \mathrm{A}_{0}$} \\
\hline Parameter & $300 \mathrm{~nm}$ & $350 \mathrm{~nm}$ & $400 \mathrm{~nm}$ & $450 \mathrm{~nm}$ & $500 \mathrm{~nm}$ \\
\hline $\mathrm{FI}$ & -0.705 & -0.802 & -0.588 & -0.308 & -0.959 \\
$\mathrm{~S}$ & -0.683 & -0.747 & -0.528 & -0.283 & -0.954 \\
$\mathrm{EAC}$ & 0.595 & 0.630 & 0.358 & 0.137 & 0.909 \\
$\mathrm{Mn}$ & 0.564 & 0.691 & 0.469 & 0.512 & 0.795 \\
$\mathrm{Mw}$ & 0.521 & 0.624 & 0.461 & 0.275 & 0.877 \\
$\mathrm{Q}^{*} \mathrm{Mn}$ & 0.603 & 0.653 & 0.332 & 0.346 & 0.589 \\
$\mathrm{Q}^{*} \mathrm{Mw}$ & 0.589 & 0.688 & 0.484 & 0.266 & 0.913 \\
\hline \multicolumn{5}{c}{$\mathrm{A}_{\text {long }} / \mathrm{A}_{0}$} \\
\hline Parameter & $300 \mathrm{~nm}$ & $350 \mathrm{~nm}$ & $400 \mathrm{~nm}$ & $450 \mathrm{~nm}$ & $500 \mathrm{~nm}$ \\
\hline $\mathrm{FI}$ & -0.887 & -0.882 & -0.897 & -0.847 & -0.822 \\
$\mathrm{~S}$ & -0.829 & -0.870 & -0.895 & -0.882 & -0.893 \\
$\mathrm{EAC}$ & 0.863 & 0.886 & 0.880 & 0.876 & 0.874 \\
$\mathrm{Mn}$ & 0.731 & 0.691 & 0.686 & 0.637 & 0.598 \\
$\mathrm{Mw}$ & 0.817 & 0.851 & 0.868 & 0.843 & 0.842 \\
$\mathrm{Q}^{*} \mathrm{Mn}$ & 0.652 & 0.557 & 0.526 & 0.468 & 0.399 \\
$\mathrm{Q}^{*} \mathrm{Mw}$ & 0.871 & 0.875 & 0.882 & 0.844 & 0.824 \\
\hline \multicolumn{5}{c}{$\Delta \mathrm{A}_{\text {short }} / \Delta \mathrm{A}_{\text {long }}$} \\
\hline Parameter & $300 \mathrm{~nm}$ & $350 \mathrm{~nm}$ & $400 \mathrm{~nm}$ & $450 \mathrm{~nm}$ & $500 \mathrm{~nm}$ \\
\hline $\mathrm{FI}$ & -0.402 & -0.075 & -0.187 & -0.098 & 0.149 \\
$\mathrm{~S}$ & -0.326 & -0.057 & -0.191 & -0.099 & 0.248 \\
EAC & 0.430 & 0.223 & 0.364 & 0.235 & -0.119 \\
$\mathrm{Mn}$ & 0.368 & 0.065 & 0.187 & -0.143 & 0.024 \\
$\mathrm{Mw}$ & 0.460 & 0.210 & 0.240 & 0.091 & -0.130 \\
$\mathrm{Q}^{*} \mathrm{Mn}$ & 0.216 & -0.059 & 0.211 & -0.042 & 0.179 \\
$\mathrm{Q}^{*} \mathrm{Mw}$ & 0.479 & 0.199 & 0.267 & 0.124 & -0.086 \\
\hline
\end{tabular}




\section{Supplementary Figures}
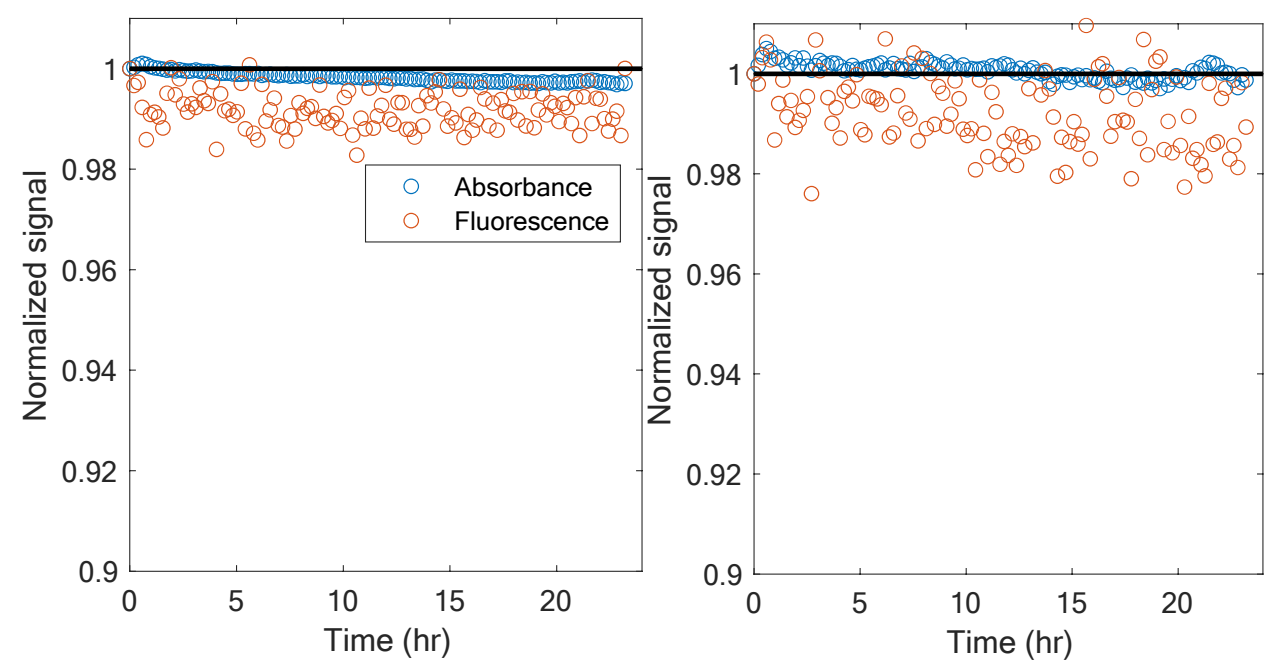

Figure S 1. Normalized intensities at 350 (left) and $450 \mathrm{~nm}$ (right) excitation for SRFA in the absence of $\mathrm{NaBH}_{4}$.

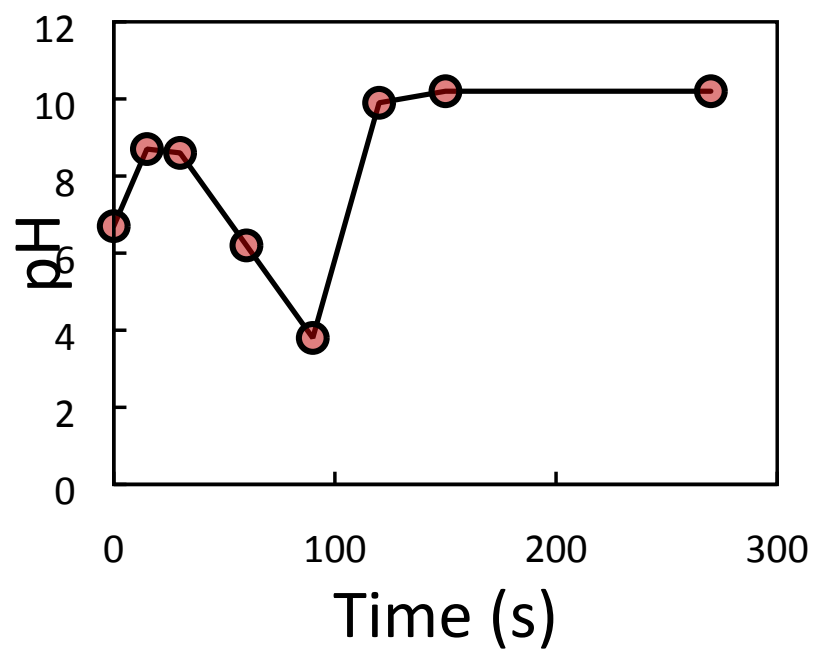

Figure $\mathrm{S} 2$. Kinetics of $\mathrm{pH}$ changes upon addition of $66 \times$ mass excess $\mathrm{NaBH}_{4}$ to Suwannee River fulvic acid initially at $\mathrm{pH} 6.7$. 


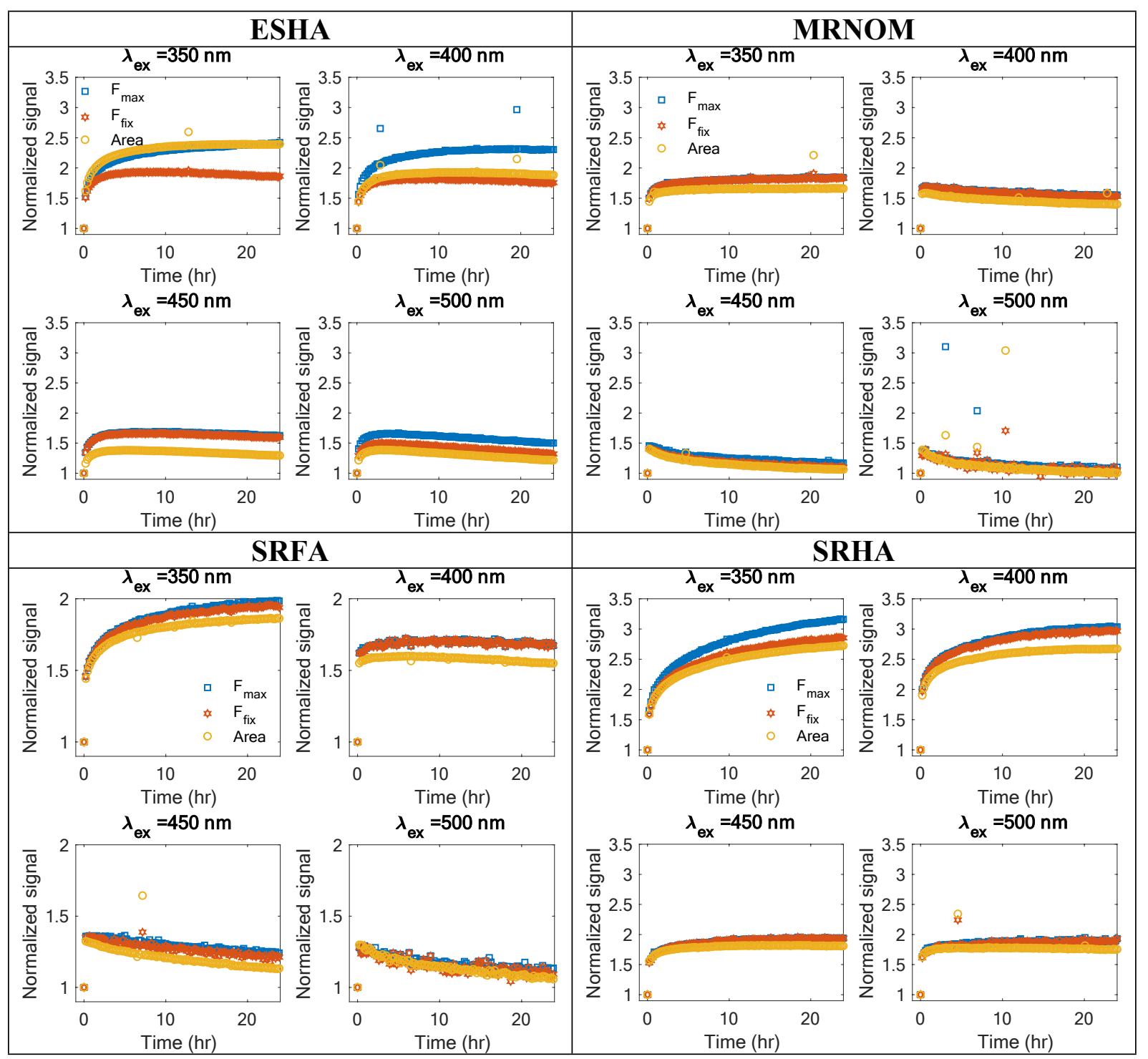

Figure S 3. Comparison of quantitative fluorescence metrics for fluorescence kinetics during reduction of Elliot Soil humic acid (ESHA), Mississippi River natural organic matter (MRNOM), Suwannee River fulvic acid (SRFA), and Suwannee River humic acid (SRHA). Metrics include the maximum fluorescence intensity $\left(\mathrm{F}_{\max }\right)$, fluorescence intensity at a fixed emission wavelength (emission maximum of unreduced sample, $\mathrm{pH} 10.0$ ), and integrated fluorescence area at the indicated excitation wavelength. 


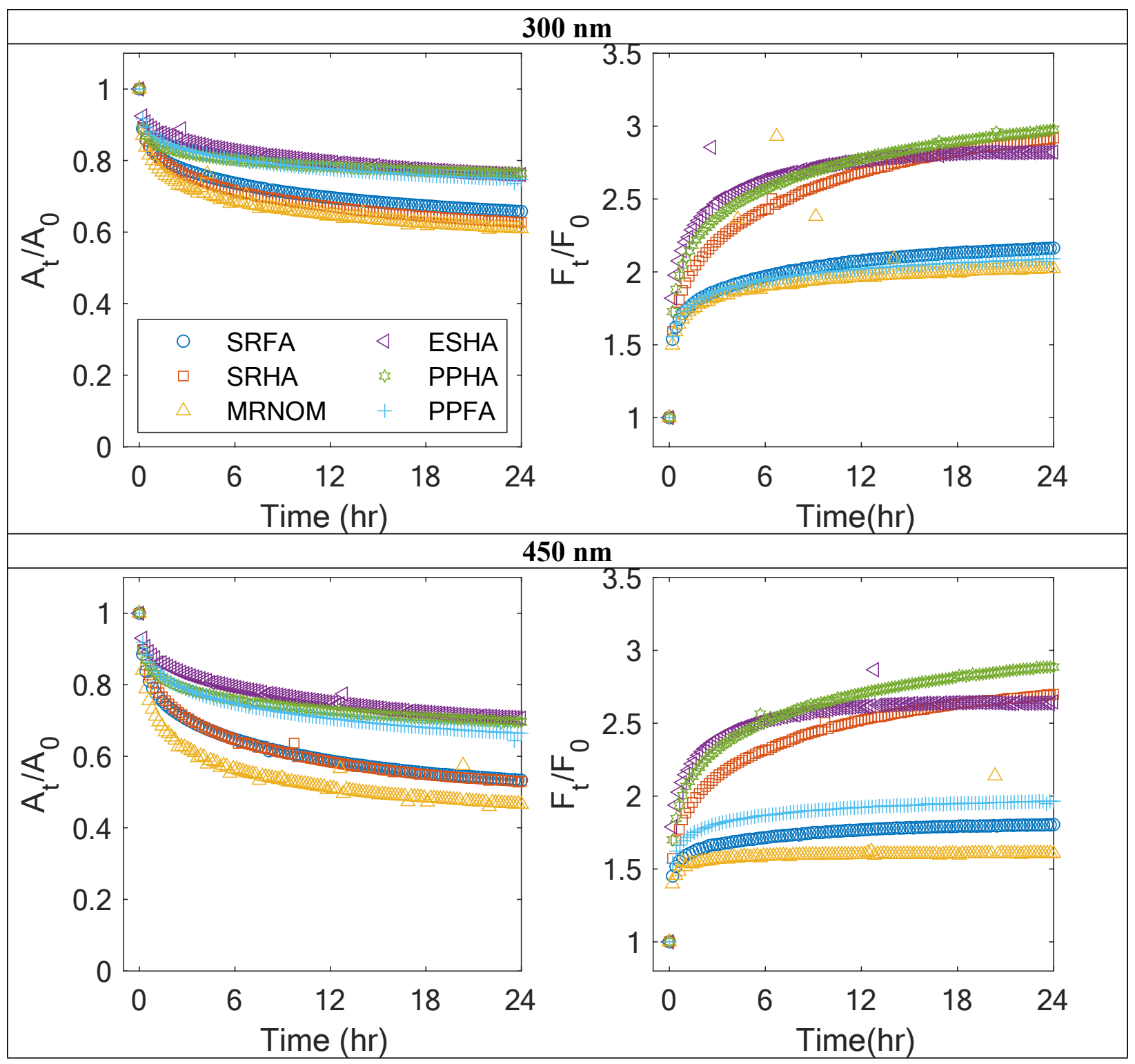

Figure S 4. Kinetics of absorbance and fluorescence changes observed during borohydride reduction of for all samples in this study at 300 and $450 \mathrm{~nm}$. Data at other excitation wavelengths are shown in Figures 1 and 3 of the main manuscript. Legend in top left plot applies to all panels. The spikes in the data are from light scatter from bubbles resulting from gas evolution during borohydride reduction. 

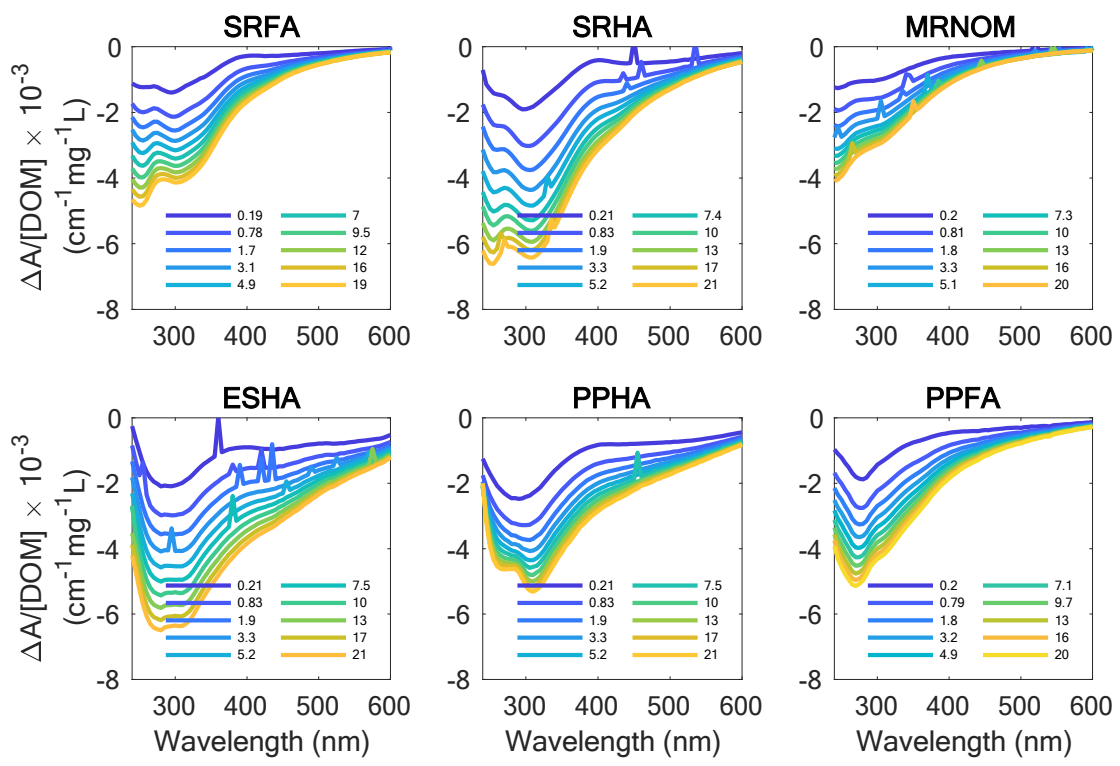

Figure $\mathrm{S} 5$. Time evolution of mass-normalized absorbance difference $\left(\triangle \mathrm{A} / \mathrm{A}_{0}\right)$ for $\mathrm{DOM}$ isolates during reduction with $66 \mathrm{x}$ mass excess sodium borohydride. $\mathrm{A}_{0}$ corresponds to $\mathrm{pH} 10$, unreduced sample. Legend labels refer to reduction time in hours. The spikes in the data are from light scatter from bubbles resulting from gas evolution during borohydride reduction.
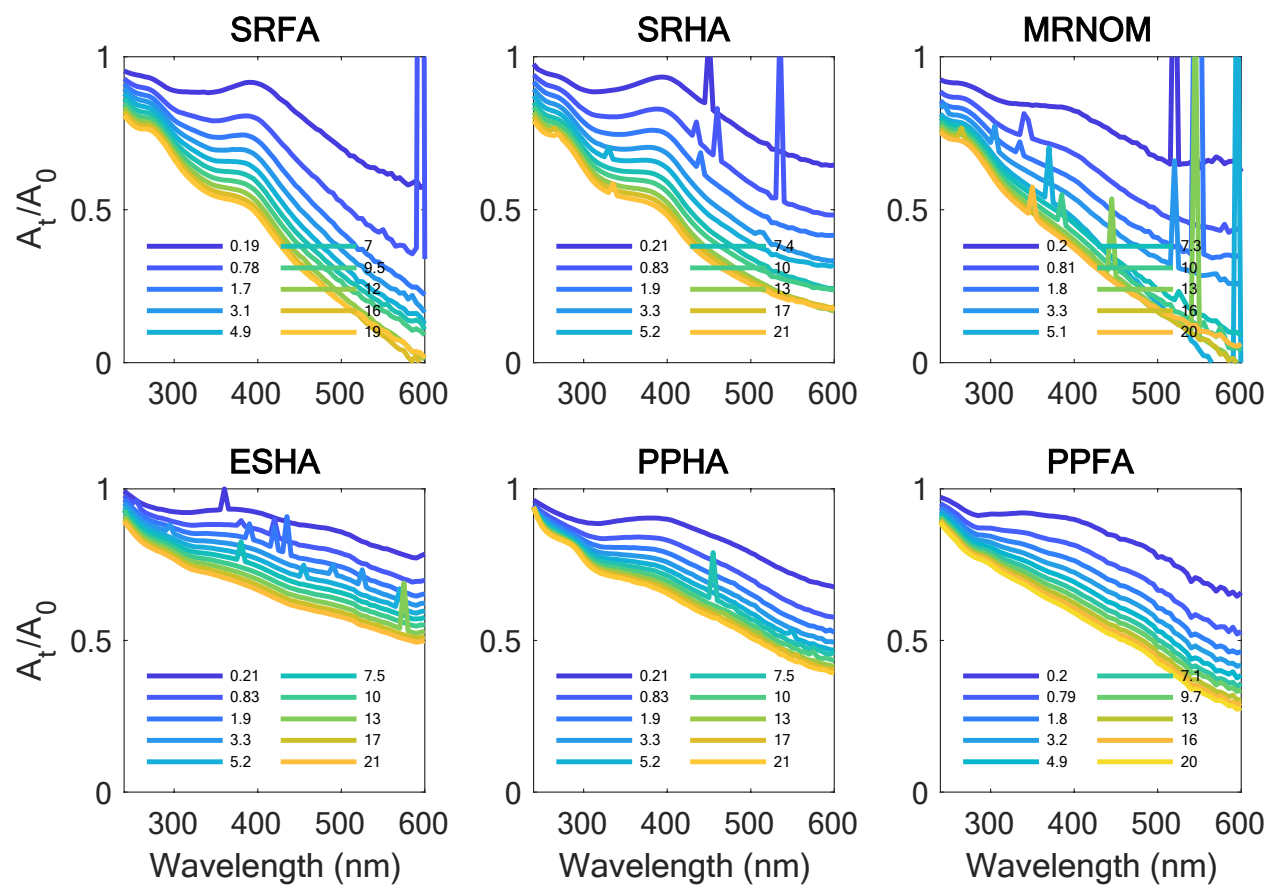

Figure $\mathrm{S}$ 6. Time evolution of absorbance attenuation $\left(\mathrm{A}_{\mathrm{t}} / \mathrm{A}_{0}\right)$ for DOM isolates during reduction with $66 \mathrm{x}$ mass excess sodium borohydride. $\mathrm{A}_{0}$ corresponds to $\mathrm{pH} 10$, unreduced sample. Legend labels refer to reduction time in hours. The spikes in the data are from light scatter from bubbles resulting from gas evolution during borohydride reduction. 

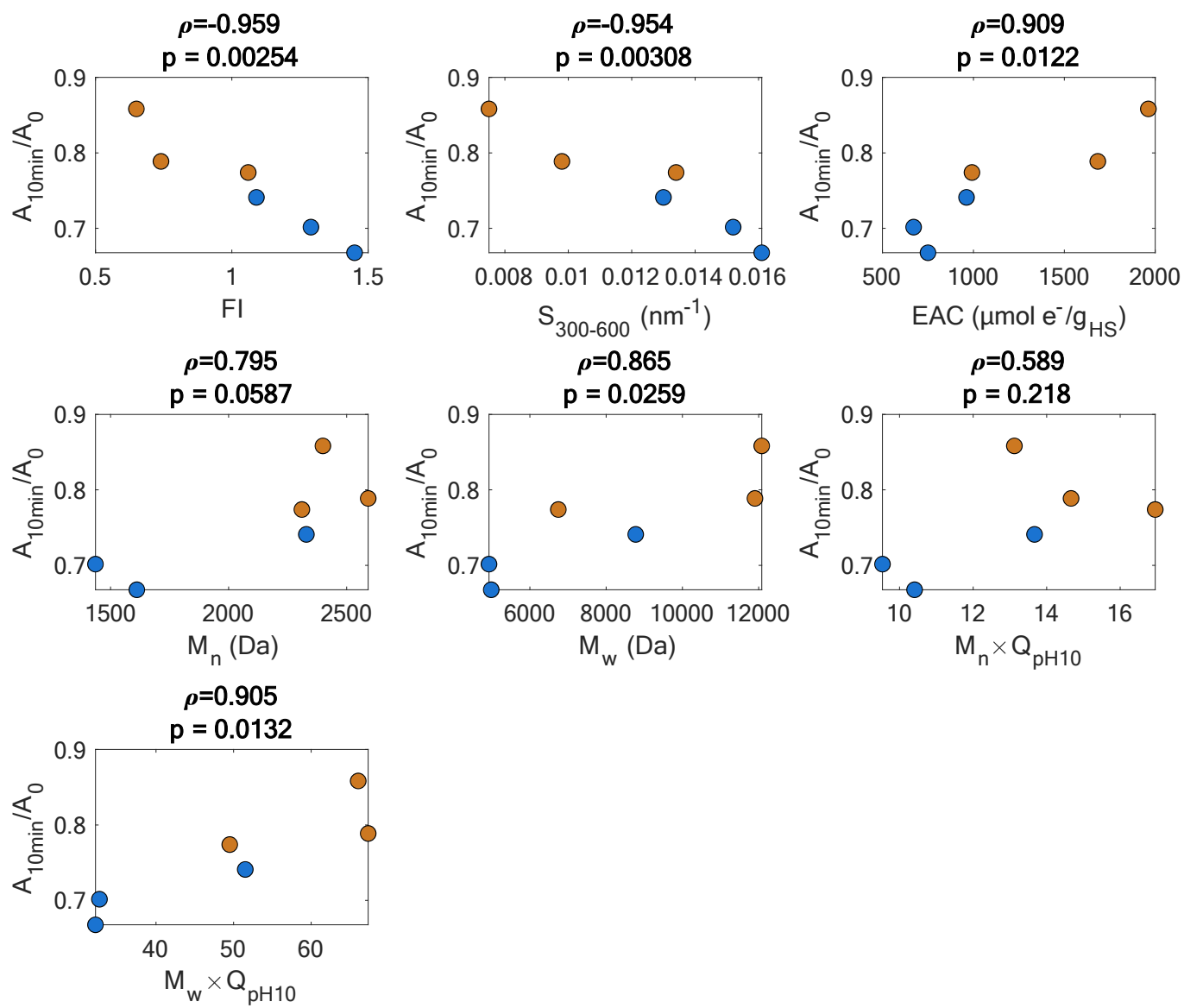

Figure S 7. Relationships between DOM physicochemical properties and fractional absorbance attenuation after $10 \mathrm{~min}$ of reduction with $66 \mathrm{x}$ mass excess sodium borohydride $\left(\mathrm{A}_{10 \mathrm{~min}} / \mathrm{A}_{0}\right)$ where $\mathrm{A}_{0}$ refers to the $\mathrm{pH} 10$, unreduced sample. Blue circles are for aquatic isolates (SRFA, SRHA, MRNOM) and brown circles are for soil isolates (ESHA, PPHA, PPFA). Pearson's correlation coefficient $(\rho)$ and $p$-value are shown for each relationship. Physicochemical properties include the fluorescence index $(\mathrm{FI})$, spectral slope $\left(\mathrm{S}_{300-600}\right)$, electron accepting capacity $(\mathrm{EAC})$, numberaverage molecular weight $\left(\mathrm{M}_{\mathrm{n}}\right)$, weight-average molecular weight $\left(\mathrm{M}_{\mathrm{w}}\right)$, number-average charge/molecule $\left(\mathrm{M}_{\mathrm{n}} \mathrm{Q}_{\mathrm{pH} 10}\right)$, and weight-average charge/molecule $\left(\mathrm{M}_{\mathrm{w}} \mathrm{Q}_{\mathrm{pH} 10}\right)$. 

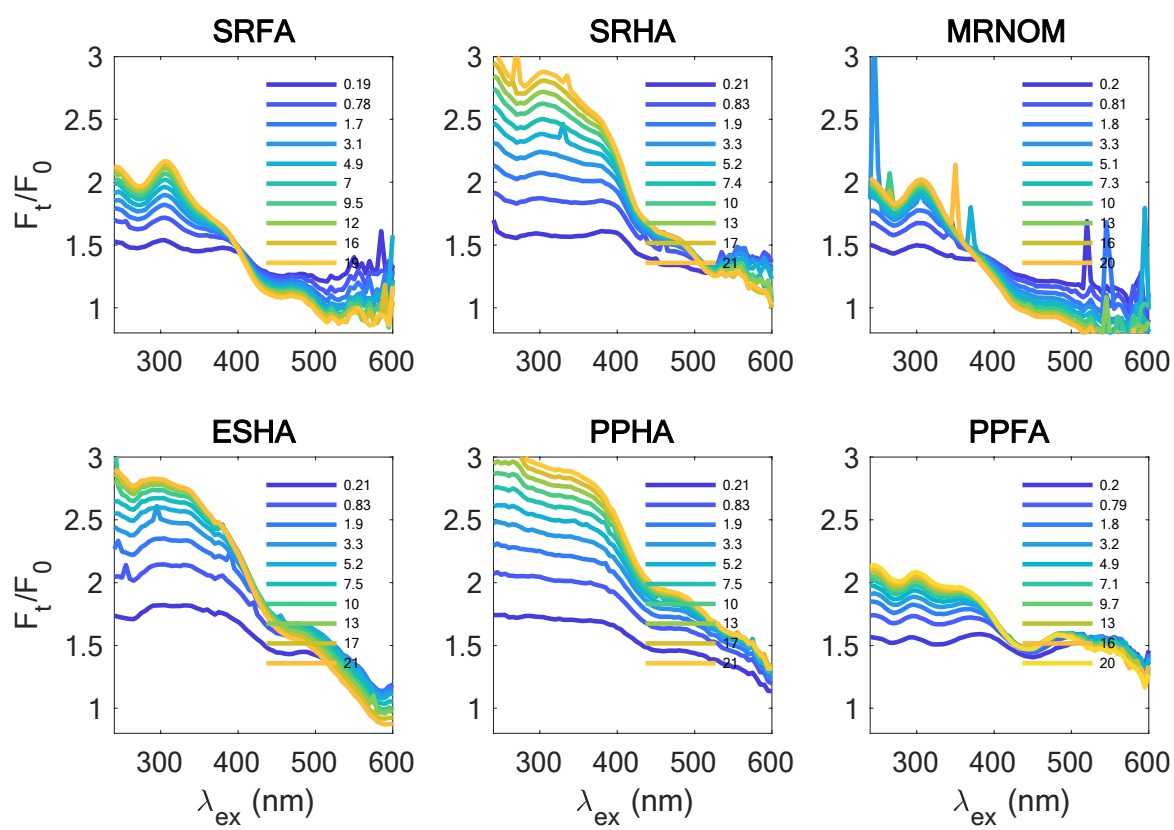

Figure S 8. Time evolution of fluorescence enhancement $\left(\mathrm{F}_{t} / \mathrm{F}_{0}\right)$ for DOM isolates during reduction with 66x mass excess sodium borohydride. $F_{t}$ refers to integrated fluorescence emission at the specified excitation wavelength. $\mathrm{F}_{0}$ corresponds to $\mathrm{pH} 10$, unreduced sample. Legend labels refer to reduction time in hours. The spikes in the data are from light scatter from bubbles resulting from gas evolution during borohydride reduction.
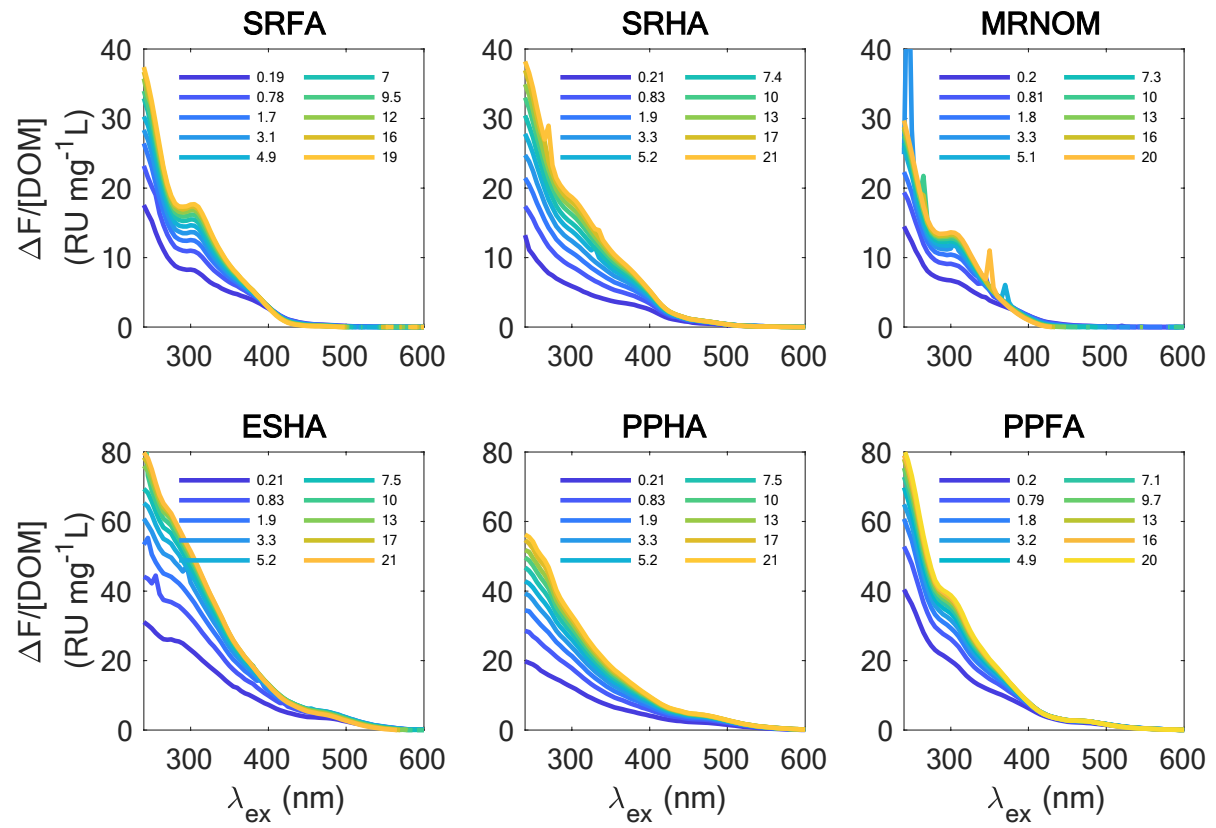

Figure S 9. Time evolution of mass-normalized integrated fluorescence emission $\left(\Delta F_{t} / F_{0}\right)$ for DOM isolates during reduction with $66 \mathrm{x}$ mass excess sodium borohydride. $\mathrm{F}_{0}$ corresponds to $\mathrm{pH}$ 10 , unreduced sample. Legend labels refer to reduction time in hours. The spikes in the data are from light scatter from bubbles resulting from gas evolution during borohydride reduction. 

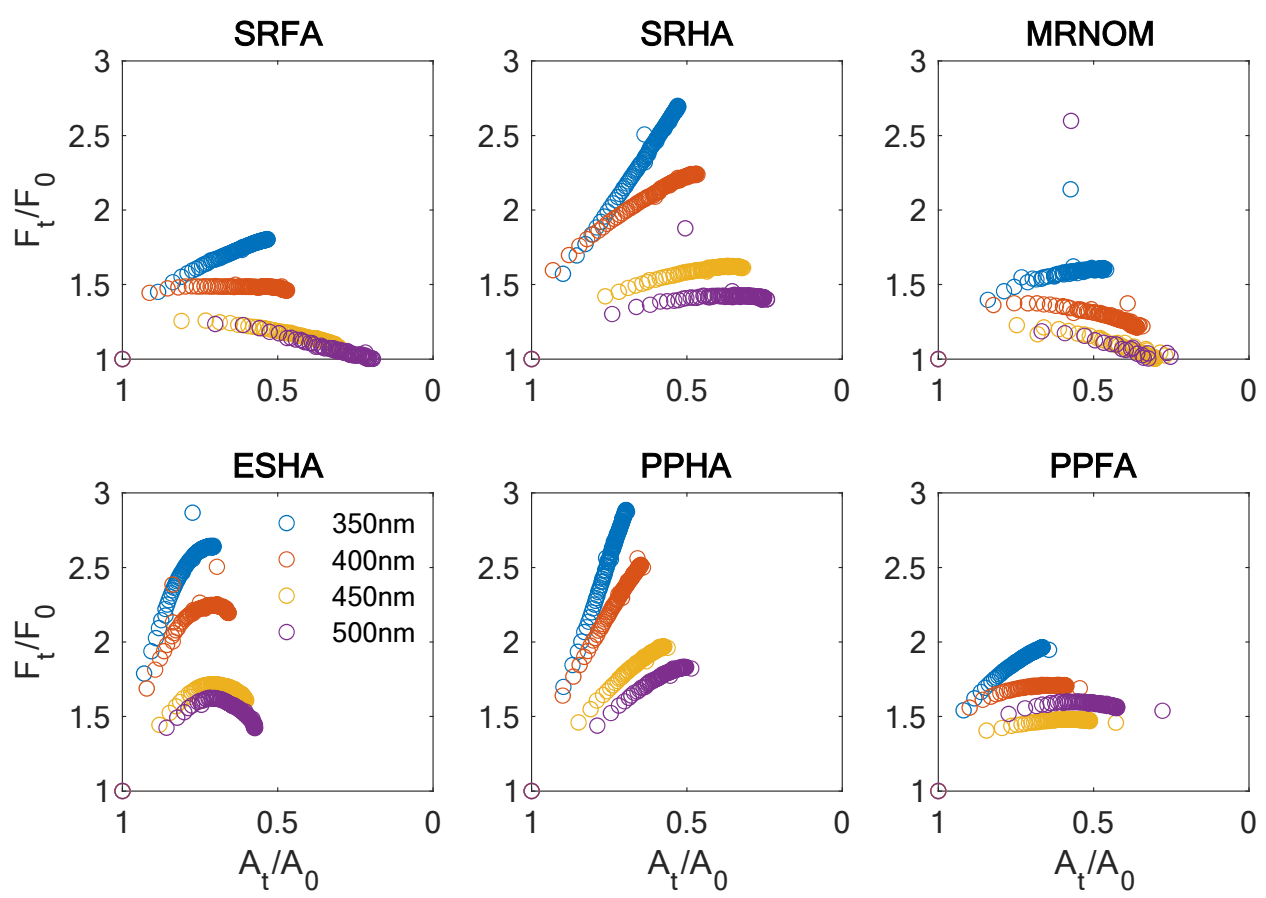

Figure S 10. Correlation of fluorescence enhancement $\left(\mathrm{F}_{t} / \mathrm{F}_{0}\right)$ and absorbance attenuation $\left(\mathrm{A}_{t} / \mathrm{A}_{0}\right)$ for DOM isolates during reduction with $66 \mathrm{x}$ mass excess sodium borohydride. $\mathrm{F}_{\mathrm{t}}$ refers to integrated fluorescence emission at the specified excitation wavelength $(350,400,450$, or $500 \mathrm{~nm})$ and $\mathrm{F}_{0}$ refers to $\mathrm{pH} 10$, unreduced sample. $\mathrm{A}_{\mathrm{t}}$ refers to absorbance at the specified excitation wavelength and $\mathrm{A}_{0}$ refers to the $\mathrm{pH} 10$, unreduced sample. The spikes in the data are from light scatter from bubbles resulting from gas evolution during borohydride reduction.
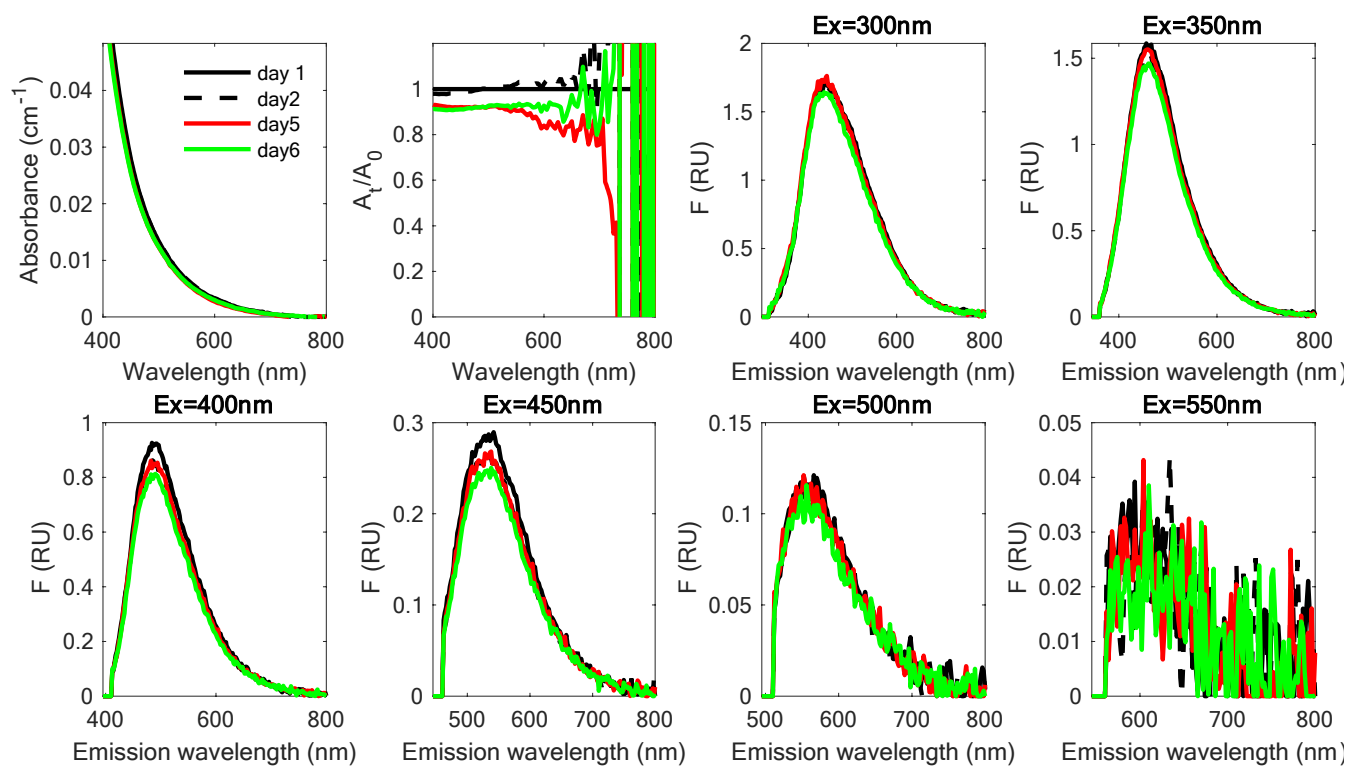

Figure S 11. Absorbance and fluorescence spectra collected over a six-day incubation period for Suwannee River fulvic acid in $10 \mathrm{mM}$, pH 10.0 borate buffer. 

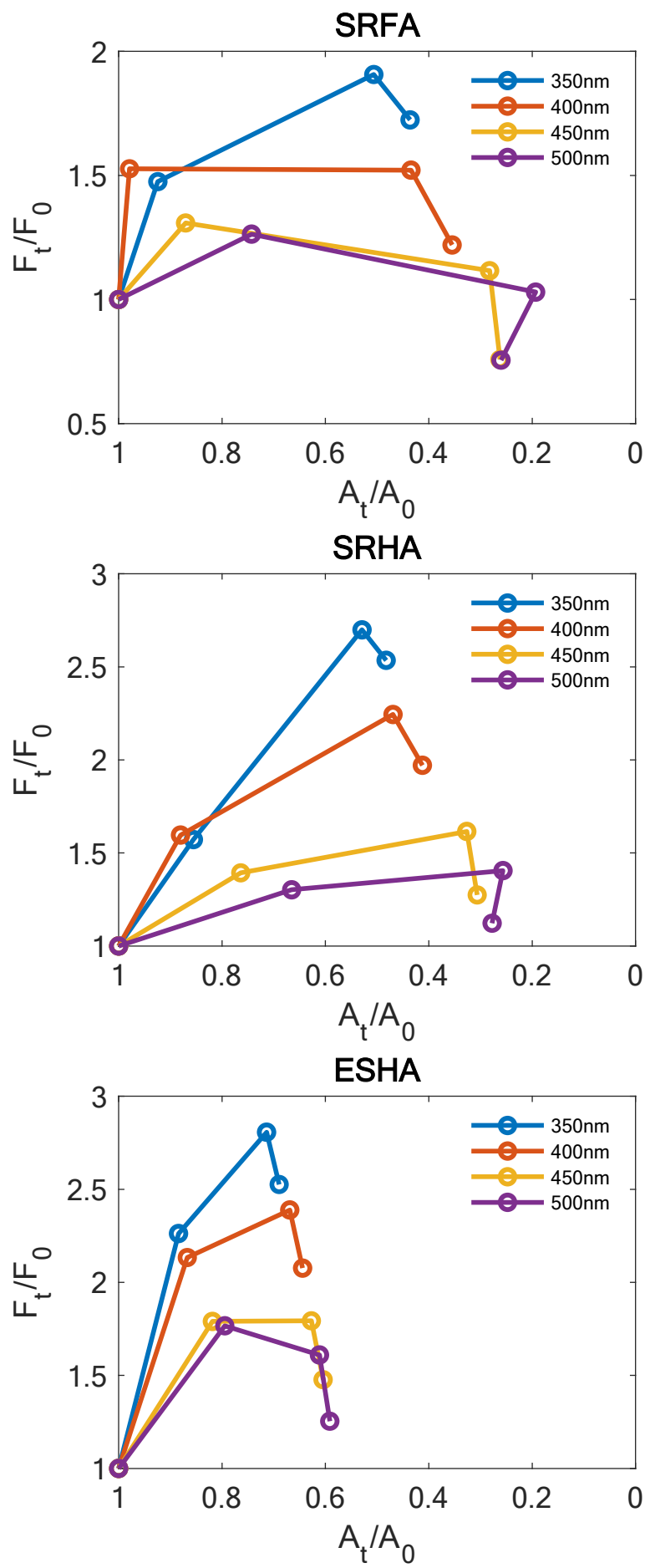

Figure S 12. Correlation of fluorescence enhancement $\left(F_{t} / F_{0}\right)$ and absorbance attenuation $\left(A_{t} / A_{0}\right)$ for DOM isolates during reduction with 66x mass excess sodium borohydride measured at $10 \mathrm{~min}$, $24 \mathrm{hr}$, and 7 days. $F_{t}$ refers to integrated fluorescence emission at the specified excitation wavelength $(350,400,450$, or $500 \mathrm{~nm})$ and $F_{0}$ refers to $\mathrm{pH} 10$, unreduced sample. $A_{t}$ refers to absorbance at the specified excitation wavelength and $\mathrm{A}_{0}$ refers to the $\mathrm{pH} 10$, unreduced sample. 

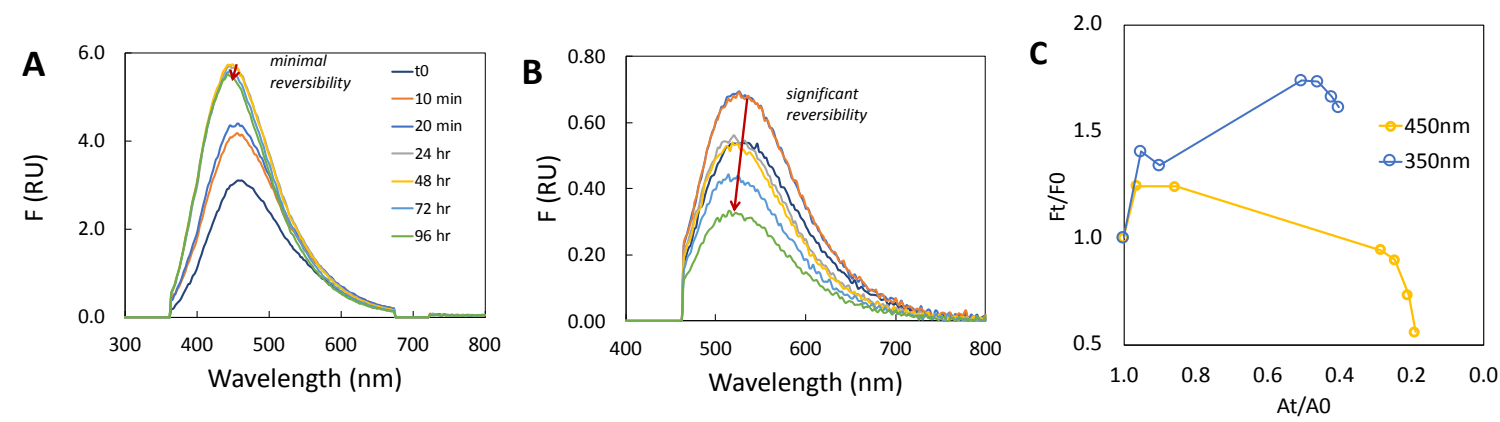

Figure S 13. Fluorescence spectra for Suwannee River fulvic acid (SRFA) measured at $350 \mathrm{~nm}$ (A) and $450 \mathrm{~nm}$ (B) excitation over a five-day period during reaction with 66x mass excess sodium borohydride. (C) Correlation of fluorescence enhancement $\left(\mathrm{F}_{t} / \mathrm{F}_{0}\right)$ and absorbance attenuation $\left(\mathrm{A}_{\mathrm{t}} / \mathrm{A}_{0}\right)$ for SRFA measured at $10 \mathrm{~min}, 20 \mathrm{~min}, 24 \mathrm{hr}, 48 \mathrm{hr}, 72 \mathrm{hr}$, and $96 \mathrm{hr}$.
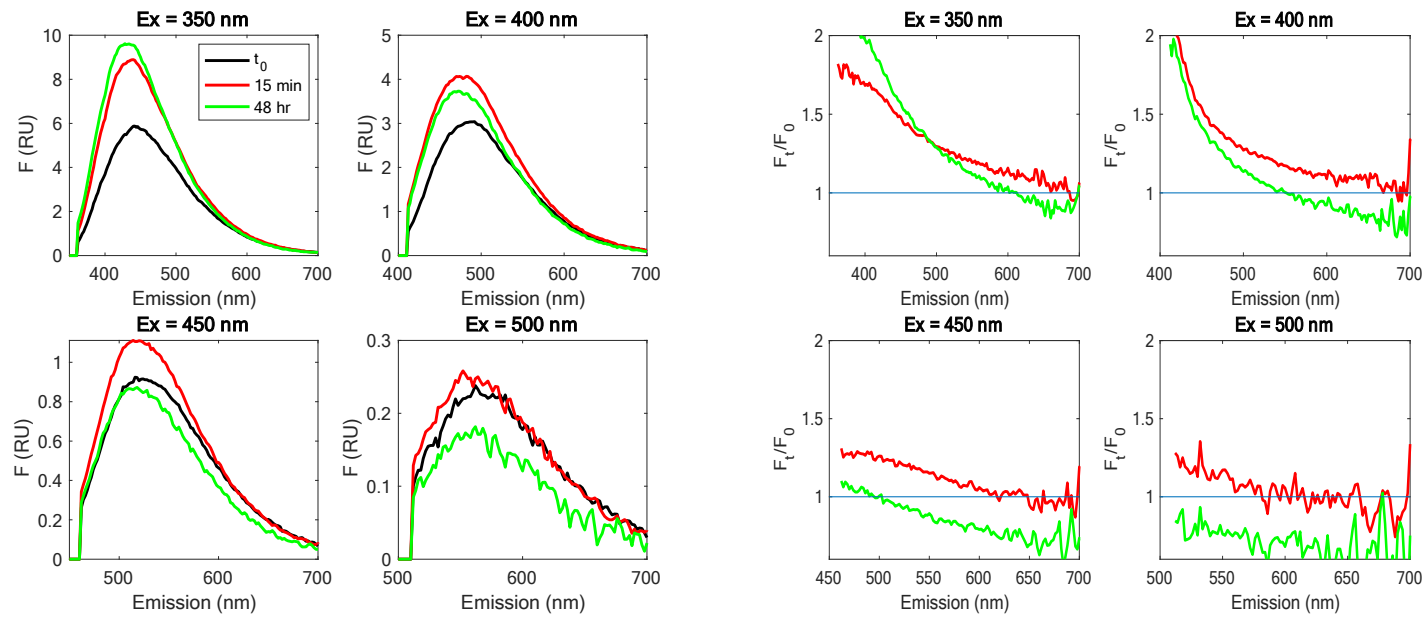

Figure S 14. The effect of 66x mass excess sodium borohydride reduction on the fluorescence emission spectra of Pony Lake fulvic acid (PLFA). Black lines correspond to the unreduced sample at $\mathrm{pH} 10$, red lines correspond to the reduced sample $\sim 15 \mathrm{~min}$ after borohydride reduction, and the green lines correspond to $48 \mathrm{hr}$ post reduction.

\section{References}

1. Kothawala, D. N.; Murphy, K. R.; Stedmon, C. A.; Weyhenmeyer, G. A.; Tranvik, L. J., Inner Filter Correction of Dissolved Organic Matter Fluorescence. Limnology and Oceanography: Methods 2013, 11, (12), 616-630.

2. McAdams, B. C.; Aiken, G. R.; McKnight, D. M.; Arnold, W. A.; Chin, Y.-P., High Pressure Size Exclusion Chromatography (Hpsec) Determination of Dissolved Organic Matter Molecular Weight Revisited: Accounting for Changes in Stationary Phases, Analytical Standards, and Isolation Methods. Environmental Science \& Technology 2018, 52, (2), 722-730. 
3. Aeschbacher, M.; Sander, M.; Schwarzenbach, R. P., Novel Electrochemical Approach to Assess the Redox Properties of Humic Substances. Environmental Science \& Technology 2010, 44, (1), 87-93.

4. $\quad$ Aeschbacher, M.; Graf, C.; Schwarzenbach, R. P.; Sander, M., Antioxidant Properties of Humic Substances. Environmental Science \& Technology 2012, 46, (9), 4916-4925.

5. Ritchie, J. D.; Perdue, E. M., Proton-Binding Study of Standard and Reference Fulvic Acids, Humic Acids, and Natural Organic Matter. Geochimica et Cosmochimica Acta 2003, 67, (1), 85-96.

6. Driver, S. J.; Perdue, E. M., Acid-Base Chemistry of Natural Organic Matter, Hydrophobic Acids, and Transphilic Acids from the Suwannee River, Georgia, as Determined by Direct Potentiometric Titration. Environmental Engineering Science 2015, 32, (1), 66-70. 